\title{
Sense and sensibility: consumers and technological brand experience
}

Razão e sensibilidade: consumidores e experiência de marcas tecnológicas

Liana Holanda Nepomuceno Nobre

Universidade Federal Rural do Semi-Arido (UFERSA), Brazil, liananobre@ufersa.edu.br

Álvaro Fabiano Pereira de Macêdo

Universidade Federal Rural do Semi-Arido (UFERSA), Brazil, alvarofabiano@ufersa.edu.br

Simone Gurgel de Brito

Universidade Estadual do Rio Grande do Norte (UERN), Brazil, simonegurgel@uern.br

Valdemar Siqueira Filho

Universidade Federal Rural do Semi-Arido (UFERSA), Brazil, dema@ufersa.edu.br

\begin{abstract}
In the brand management field, studies on brand experiences that consider cognitive and behavioural dimensions have sought to examine consumers' relationships with brands. The current research analysed consumer brand experiences to determine whether technological brand consumption is different from non-technological brand consumption. Quantitative analysis of the data was conducted using confirmatory factor analysis and analysis of variance. Four dimensions of brand experiences were tested: sensorial, affective, behavioural and intellectual. The 10 selected brands included technological and nontechnological ones. The study population was 230 university business students attending a Brazilian university. The results indicate that consumers perceive a difference between their experiences with technological and non-technological brands. Distinctions are primarily based on brands' performance in terms of sensorial, emotional and intellectual dimensions. The latter cover cognitive capacity, creativity and problem-solving performance, which are stronger in experiences with technological brands.
\end{abstract}

Keywords: Brand experience, technological brands, consumer behaviour.

\section{Resumo}

No campo da gestão da marca, estudos sobre a experiência da marca considerando as dimensões cognitivas e comportamentais - analisam as relações do consumidor com as marcas. O presente artigo analisa experiências de marca visando identificar se o consumo de marcas tecnológicas é diferente do de marcas não tecnológicas. Uma análise quantitativa foi realizada, e os dados foram analisados pela Análise de Fator de Confirmação e Análise de Variância (ANOVA). Foram testadas quatro dimensões da experiência da marca: sensorial, afetivo, comportamental e intelectual. Foram analisadas dez marcas selecionadas, entre tecnológicas e não tecnológicas. A população desse estudo foi composta por 230 universitários da área de negócios de uma universidade brasileira. Os resultados indicam que os consumidores percebem diferenças na sua experiência com marcas tecnológicas e não tecnológicas, que se baseiam principalmente nas dimensões sensorial, que se refere aos sentimentos, e intelectual, em relação à capacidade cognitiva, criatividade e desempenho de resolução de problemas, que são mais fortes na experiência com marcas tecnológicas.

Palavras-chave: Experiência de marca, marcas tecnológicas, comportamento do consumidor.

\section{Introduction}

The evolution of the communication process and the speed of technological change are promoting important advances in the definition of strategies for brand management. The analysis of aspects of the relationship between brands and consumers may generate indicators for planning marketing actions geared toward the competitive differentiation of products and services. Fournier (1998) defended the premise that people relate to brands in the same way that they relate to people. That relationship brings meaning to peoples' lives and may promote the creation of bonds with, or loyalty to, certain brands.

According to Breivik and Thorbjørnsen (2008), studies on brand relations help us to better understand a few indicators of loyalty, learn about consumer needs, as well as help with product development and improve corporate marketing activities. Meanwhile, even though relevant theoretical models are found in the literature (Fournier, 1998; Rusbult, 1980), few empirical studies help us understand the relationship between consumers and brands.
Consumer relations with a brand may be affected by the brand experience. Brakus, Schmitt and Zarantonello (2009) define brand experience as an internal subjective response by the consumer (sensorial and cognitive feeling), which can occur in the most varied of environments, and which involves consumers in search of, purchasing, gaining, or consuming products or services. Understanding how consumer brand experiences occur is considered critical in developing marketing strategies. Brakus et al. (2009) proposed a tool for measuring brand experience composed of four dimensions-sensorial, affective, behavioural, and intellectual-when developing new studies and improving marketing actions. For the current consumer market, brands related to technological products are excessively present in consumers' routines. Thus, considering the four dimensions of the tool proposed by Brakus et al. (2009), there may be differences in consumer experience with technological and non-technological brands. With the aim of identifying any differences in brand experience with technological and non-technological brand consumption and using the tool proposed by Brakus et al. (2009), the current 
paper analyses consumer experience with brands of different product categories. This goal was identified as a key research and management question (Schmitt, Brakus, \& Zarantonello, 2014) as it highlights which setting of brand dimensions may impact on brand experiences. This study answers the call of Khan and Rahman (2015) by providing a brand experience research in emerging economies with a big consumer market. Furthermore, this article presents a review of literature that encompasses concepts and studies on the relational approach, brand experience, and technological brands. In the following text, methods of collecting and statistically processing data are presented, and in conclusion, the obtained results are described and analysed.

\section{Theoretical background}

Given the large volume of investment in planning and implementing brands, brand management has attracted the attention of managers and researchers alike since the mid-1980s. Heding, Knudtzen and Bjerre (2009) organised several perceptions of brands into seven approaches that vary from the economic approach, which consider the brand to be an element of the traditional marketing mix, to the cultural approach, which considers the brand to be a part of a complex cultural context. The other approaches suggested by the authors are as follows: the brand identity approach, brand image, consumer-based approach, personality approach, relational approach, and brand communities. This paper uses the prerequisites of the relational approach that considers the brand to be a partner of the consumer. According to that perspective, Stone and Woodcock (1998) highlight consumers' deep knowledge as a determining factor for developing perceptions and attitudes related to a product or service, thus transforming itself into positive behaviour regarding that brand. This perspective indicates that the focus has shifted to the relationship of individuals with brands.

\subsection{Relational approach}

The relational approach originated in Fournier's (1998) study, which took a phenomenological approach to identify how consumers experimented with brand relations. The study identified fifteen different forms of relationships, which are quite similar to human relationships (Heding et al., 2009). Considering that the durability and quality of relations may influence the consumer's evaluation, Fournier (1998) proposed a construct known as Brand Relation Quality, which comprises six relational factors: love/passion, auto-connection, interdependence, compromise, intimacy, and partnership. That study led the academic community to investigate beyond the mere identification of existing relationship forms-to go on and show that those relationships may influence brand evaluation by consumers.

Before the appearance of the relational approach, however, some research considering aspects of brand relations was already being developed: Zaichkowisky (1994), while analysing consumer involvement with brands, noted the relationship between an individual and an object that is based on inherent needs, values, and interests. Those characteristics are elements of the relational approach, and according to Kinard and Capella (2006), this approach comprises the characteristics of services and the personal involvement of individuals.

Relationships are the primary goal of most corporations (Aaker, Fournier, \& Brasel, 2008), and research has shown that relationships are influenced by the personality of the parties involved. Prado (2004) decomposed two significant components in the evaluation of the brand relationship from a consumer's perspective: global satisfaction, that involves perceived quality, affectivity and benefits generated by long relationships; and relationship quality, that involves trust, commitment, loyalty and relationship intensity (frequency and variety of products). Those elements, when jointly analysed, make up the type of achieved relationship between the consumer and the brand, resulting in a range of possibilities for brand identification, since extremely negative relationships to positive ones.

Further studies show the personification of the brand (Aaker, 1997; Aaker, Benet-Martínez, \& Garolera, 2001): consumers imagine that brands exist in a continuum that is equivalent to human relationships, from intimacy to awkwardness and from nurture to animosity (Sherry, 2006); thus, brands could be perceived to be friendly, strange, adverse, among others. Aaker et al. (2008) list three characteristics as being the most influential ones in strengthening this relationship-status, enthusiasm, and vitality-furthermore, they also make an analogy of brand relationships with personal relationships. More recently, Gorbaniuk, Razmus, Firlej, Lebiedowicz and Leszczyńskig (2017) findings show four dimensions for that personification of corporations and brands: innovativeness, that reflects the idea of dynamism and resourcefulness of the brand; openness to others, that contemplates the idea of interaction; stability says how resilient and how persistent the brand is; and Machiavellianism, that involves negative adjectives associated to the brand or corporation.

Finally, studies allude to brands as helping consumers to reach their goals, serving social integration, providing self-esteem, and allowing the individual to shine uniquely or as part of a specific community (Escalas \& Bettman, 2005). These ideas are corroborated by Fournier (2009), who, ten years after her seminal work, states that brand relationships are loaded with meaning that help people carry on with their lives. Fournier (2009) noted that many brand relationships are considered functional as they concentrate mostly on extracting greater exchange value for the company and the brand. However, Fournier (2009) indicates that people are more interested in new social interaction derived from brand relationships than they are in brand relationships themselves.

\subsection{Brand experience}

The concept of brand experience was introduced in marketing literature by Holbrook and Hirschman (1982). They examined the theme by taking into account the irrational and emotional aspects of consumer behaviour. A few years later, Pine and Gilmore (1998) 
examined the concept of experience from the economic and valueadding aspect, beginning with a projection of memorable experiences with the products or services supplied to the consumer. Fournier (1998), in her study on brand relationships, suggested that those relationships are valid depending on the level of the experiences lived by consumers. Accordingly, the author concluded that consumers do not buy just because they like the brand or because it works well but also due to the meaning that the brand adds to their lives.

Prahalad and Ramaswamy (2004) noted that the corporation must create an environment geared toward consumer interaction, where consumers may co-create unique experiences and develop their value base, thus not being solely influenced by corporate marketing actions. The idea that brand experience is reinforced by interactions is also provided by several authors, as for them those interactions with company's brands evoke subjective and internal responses in consumers that trigger memorable experiences (Gentile, Spiller, \& Noci, 2007; Khan \& Rahman, 2016). Thus, it is a strictly personal experience that implies consumer involvement at different levels (rational, emotional, sensorial, physical, and spiritual). Brakus et al. (2009) stated that experience comes in many forms-whether it is indirect, as with consumer exposure to intangible aspects of marketing communication, or direct, when the consumer searches, buys or consumes products. Gentile et al. (2007) stated that while many studies explore the brand experience theme from a theoretical perspective, tools aimed at supporting marketing managers in composing the right stimuli to promote an excellent customer experience are still rare.

\subsubsection{A scale for brand experience}

During the past few years, with the technological environment being favourable to consumer-corporation relationships, studies that involve brand experience were once again conducted in force (Brakus et al. 2009; Lee \& Kang, 2012; Shamim \& Butt, 2013; Morgan-Thomas \& Veloutsu, 2013). That literature shows that theoretical and empirical advances in brand experience consist of means to understand and create value-adding experiences as much as they consist of proposals for measures to evaluate experience results and define competitive business strategies.

One of the most relevant studies in that field was presented by Brakus et al. (2009), who first defined a scale for measuring brand experience (Khan \& Rahman, 2015). In that study, the moments at which experiences occur were empirically analysed, as well as how they affect consumers' attitudes and judgment, along with other aspects of their behaviour. The brand experience dimensions were defined based on a wideranging, multidisciplinary bibliographical review, encompassing studies from the fields of psychology and cognitive science and studies applied to experimental marketing and management. By way of confirmatory factor analysis, the best model for the brand experience construct consisted of four factors (sensorial, affective, behavioural, and intellectual) as shown in Figure 1.

Figure 1 - Four factor model for Brand Experience

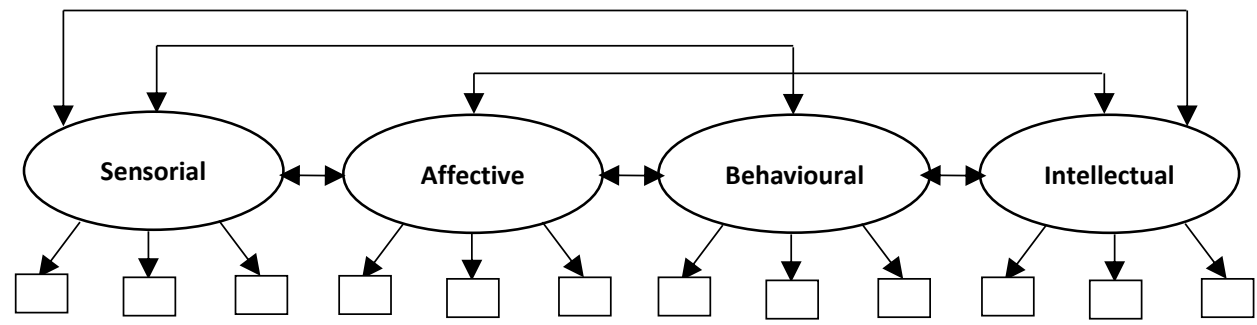

Source: Adapted from Brakus et al. (2009)

The scale proposed by Brakus et al. (2009) went through validity and accuracy tests, as well as discrimination analysis, regarding other scales from brands present in the literature. After five study stages, the final model consisted of twelve items distributed among factors, as shown in Table 1.

\section{Table 1 - Brand Experience Scale}

\begin{tabular}{|c|c|}
\hline Dimension & Item \\
\hline \multirow{3}{*}{ Sensorial } & This brand causes a strong impression in my visual senses and/or other senses. \\
\hline & I consider this brand to be interesting from a sensorial perspective. \\
\hline & This brand does not appeal to my senses. \\
\hline \multirow{3}{*}{ Affective } & This brand triggers emotions and feelings. \\
\hline & I do not have strong emotions regarding this brand. \\
\hline & This brand appeals to my emotions. \\
\hline \multirow{3}{*}{ Behavioural } & I get involved in action and behaviour when I use this brand. \\
\hline & This brand brings out social behaviour and gives me social experiences. \\
\hline & This brand is not geared for action. \\
\hline \multirow{3}{*}{ Intellectual } & I get involved in thoughts when I see this brand. \\
\hline & This brand does not make me think. \\
\hline & This brand stimulates my curiosity and problem-solving acumen. \\
\hline & Source: Adapted from Brakus et al. (2009). \\
\hline
\end{tabular}


The sensorial dimension involves stimuli aimed at consumers' senses, such as sight, smell, touch, taste, and hearing. According to Pontes (2012), there are several situations in which organisations may develop such stimuli, for instance, the products and their packaging, staff uniforms, establishment environment and architecture, and publicity stunts, among other related things.

The affective dimension involves elements linked with humour, feelings, and emotions that affect the individual (Semprebom, 2011). The intensity of emotional experiences changes according to the consumer's state of mind and the consumption situation. According to Pontes (2012), the temperament and emotional availability of an individual upon entering the experience affect the mood and intensity of their feelings.

The behavioural dimension is linked to values and beliefs of individuals according to their lifestyles and behaviour. Schmitt (2009) mentioned several categories that are linked to action: physical aspects, motor actions, body signs, influence from the environment on physical desire, nonverbal behaviour, lifestyle, behavioural changes, self-awareness, and induction from unplanned actions. This category is divided into two broad groups: actions linked to the body and actions linked to lifestyle.

Finally, the intellectual dimension is linked to experiences that stimulate the client to think, arousing their creativity and curiosity, as well as stimulating debate and generating controversy (Sabiote \& Ballester, 2011). This is a dimension that involves experiences that mentally affect the consumer. According to Pontes (2012), an example of such a dimension is an experience with advertising backup that enables the consumer to think and has them thinking about the usefulness of the product to them, whether the information on the product leaflet is real or mere trickery to induce them to make the purchase. The current study uses the Brand Experience Scale developed by Brakus et al. (2009) to measure brand experience as presented in the next section.

\subsection{Technological brands}

The speed with which new products and services are being launched in the market in a highly competitive environment has motivated the increase in the number of studies that identify and explain the determining factors for consumer choice. Seetharaman et al. (2005) presented a comprehensive review of studies on experiences that may interfere with consumer choice regarding categories or multi categories of products. Different econometric and multidimensional analysis techniques are presented. Among the existing product categories, technological products are unavoidable in modern life. Despite this, few scientific studies analyse the relationship or consumer experience in particular for the category of technological products and brands. Among these studies, one work that comes to mind is that of Mick and Fournier (1998), who conducted empirical research with interviewees and developed a theoretical framework that is based on the analysis of peoples' perspectives, meaning, and behaviour regarding technological products, their purchase, or the ownership of technological products. The qualitative study resulted in a concept chart on the paradoxes of technological products and their influence on emotional reactions and behavioural strategies.

Sriram, Chintagunta and Agarwal (2010) presented a theoretical framework for modelling consumer purchasing behaviour regarding the technological product category (digital cameras, personal computers, and printers). Aspects linked to the fall in prices of these products through time, their durability, their quality, and their complementarity to other technological brands are elements of the model proposed for analysing consumers' purchasing behaviour regarding the selected technological products.

Human bodily functions are used as metaphors to analyse the communication strategy of technological brands in the study by Buchanan-Oliver, Cruz and Schroeder (2010). The authors examine the impact of image and cultural elements in the consumer's responses to concepts and technological brand experiences. In this case, a modern marketing strategy involves the use of images and experiences that associate technological brands with some aspects of a group or individual identity. This theory extrapolates the traditional market view of finding proof in the functional benefits of the products besides leading to the discussion by Mick and Fournier (1998) on the positive and negative aspects of consumers' relationship with technology.

Internet experiences have been an innovative tool-of strategic use-in motivating research in the field of consumer behaviour and brand management. Using three search engines, Google, Yahoo, and MSN, Morgan-Thomas and Veloutsou (2013) developed a model for rating brand experiences online. The study showed that positive experiences generate satisfaction, new interactions, and emotional ties with the brand. Still, the experiences depend on perceptions of utility, trust, and brand reputation.

Studies that involve technological brands have shown that emotional and cognitive aspects interfere with the perception of value attributed to the brand by the consumer. However, no studies were available that would indicate any difference in brand experience between consuming technological and nontechnological brands.

\section{Methodology}

Quantitative and descriptive research was conducted for identifying any differences in brand experience between consuming technological and non-technological brands. The primary goals were the identification and analysis of the studied phenomena (Gil, 2002). The proposed temporal slicing was a transversal study that collects information from any sample of participants only once (Hair Jr., Black, Babin, Anderson, \& Tatham., 2005; Malhotra, 2001).

The model used for measuring brand experience was adapted from Brakus et al. (2009). The authors developed this model from a study conducted in five stages. A result of the work by 
the authors was a questionnaire composed of twelve items, which were allocated in four dimensions: sensorial, affective, behavioural, and intellectual.

The data collection instrument was a structured questionnaire, the application was done in person, and the media was a computer. The questionnaire was developed and applied using Qualtrics software. Thus, the questions used in the current study are those extracted from the work done by Brakus et al. (2009) and were translated by resorting to back translation, a technique that guarantees a precise and trustworthy translation of the instrument. Ten brands were selected and submitted to a content validity check; then, they were categorised into technological and non-technological brands. The technological brands that were tested are Apple, Google, Microsoft, Motorola, and Samsung; the non-technological brands that were tested are Coca-Cola, Colgate, Gillette, Havaianas, and Nestlé. The scale used in the questionnaire is the same as the one used by Brakus et al. (2009): an adapted 7-point Likert scale that varies from "disagree completely" to "agree completely."

The population analysed in the current study includes college students from Business Management, Accounting, and Marketing from a Brazilian university. Two hundred and thirty students aged from 16 to 48 took part in the research $(58.8 \%$ were women), with $48.8 \%$ of participants aged between 20 and 25 years. Taking part in the study was voluntary, and respondents did not receive any compensation for it. Each respondent would randomly select a link for one of the available questionnaires and would then analyse two brands. This process generated 460 observations, distributed in the brands as follows: Apple (48); Coca-Cola (50); Colgate (45); Gilette (48); Google (47); Havaianas (40); Microsoft (50); Motorola (45); Nestlé (47) and Samsung (40). The collected data was used to test the convergent and discriminant validity of the model's latent variables, as well as to evaluate the trustworthiness of these constructs by using Confirmatory Factor Analysis.

\section{Results and discussion}

An exploratory analysis was conducted and no outliers or missing values were found. Before any analyses were performed, the ANOVA assumptions of homoscedasticity and normality were evaluated using Levene's test and the ShapiroWilkes test, respectively, with SPSS ${ }^{\circledR}$. The model's constructs are unidimensional, and each of them is formed by two indicators since the items of the reverse scale were taken from the model following the Semprebom (2011) model. The constructs and basic measures are detailed in Table 2 .

Table 2 - Model constructs and basic measures

\begin{tabular}{|l|c|c|c|}
\hline Dimension & $\begin{array}{c}\text { Average } \\
\text { (S.D.) }\end{array}$ & $\begin{array}{c}\text { Correlation } \\
\text { between the } \\
\text { construct's items }\end{array}$ & $\begin{array}{c}\text { Cronbach's } \alpha \\
\text { Coefficient }\end{array}$ \\
\hline Sensorial & $7.28(1.99)$ & $0.506 * *$ & 0.659 \\
\hline Affective & $5.54(2.29)$ & $0.516^{* *}$ & 0.680 \\
\hline Behavioural & $5.60(2.76)$ & $0.629 * *$ & 0.772 \\
\hline Intellectual & $6.04(2.64)$ & $0.536 * *$ & 0.697 \\
\hline
\end{tabular}

The average obtained values and their respective dispersion measures indicate a positive perception around the sensorial, affective, behavioural, and intellectual dimensions of the analysed brands, whereas the two highest-scoring dimensions were the sensorial and the intellectual ones. The bivariate correlations of indicators for all the latent variables were positive and significant $(p<0.000)$. Cronbach's alpha coefficients for the constructs prove their trustworthiness (Hair Jr. et al., 2005).

To verify the constructs that compose the proposed model, the Confirmatory Factor Analysis was adopted. The process used was the method of maximum probability estimation. The tested model had four dimensions, a sample of 460 observations, and presented good adjustment quality $\left(\mathrm{X} 2 / \mathrm{gl}=2.799^{* * *} ; \mathrm{CFI}=\right.$ 0.977; IFI = 0.977; RMSEA = 0.043).

When analysing the validity and trustworthiness of the model, first the adjustment level of indicators to the proposed dimensions was verified using a Composed Reliability indicator. This indicator allows for the testing of consistency in the model's variables. To test the convergent validity, Average Variance Extraction (AVE) was performed, using $\operatorname{Amos}^{\circledR}$. The findings are shown in Table 3.

Table 3 - Findings of confirmatory factor analysis, composed reliability, and average variance extraction of constructs

\begin{tabular}{|c|c|c|c|c|}
\hline Indicators Constructs & Sensorial & Affective & Behavioural & Intellectual \\
\hline Q2 - Sensorial & 0.790 & & & \\
\hline Q1-Sensorial & 0.627 & & & \\
\hline Q6-Affective & & 0.743 & & \\
\hline Q4-Affective & & 0.694 & & \\
\hline Q8-Behavioral & & & 0.872 & \\
\hline Q7-Behavioral & & & 0.721 & \\
\hline Q12 - Intellectual & & & & 0.864 \\
\hline Q10 - Intellectual & & & & 0.620 \\
\hline Composed Reliability (CR) & 0.77 & 0.79 & 0.86 & 0.81 \\
\hline Average Variance Extraction (AVE) & 0.64 & 0.65 & 0.76 & 0.69 \\
\hline
\end{tabular}

The composed factor reliability was considered satisfactory as these values were higher than 0.70 . The values obtained for
AVE, which represents convergent factor validity, were satisfactory, presenting values greater than 0.5 . 
Discriminatory validity indicates that the model's constructs consider different factors (Marôco, 2010). To test this validity,

the correlations between latent variables were verified in pairs.

The findings are shown in Table 4.

Table 4 - Correlation matrix and squares of variables latent in the model

\begin{tabular}{|l|c|c|c|c|}
\hline & Sensorial & Affective & Behavioural & Intellectual \\
\hline Sensorial & 1 & - & - & - \\
\hline Affective & $0.533(0.284)$ & 1 & - & - \\
\hline Behavioral & $0.376(0.141)$ & $0.658(0.433)$ & 1 & - \\
\hline Intellectual & $0.592(0.350)$ & $0.673(0.453)$ & $0.570(0.325)$ & 1 \\
\hline
\end{tabular}

For Marôco (2010), the discriminant validity may be rated by comparing the square of the correlation between factors and the AVE for each construct: in case the AVE of factors is greater than the square of the correlation between them, one may state that there is no overlapping of constructs. Thus, the square of the correlation between the sensorial and the affective dimensions is 0.284 , which is less than the AVEs of the sensorial (0.64) and affective (0.65) factors. The remaining constructs of the model were tested so as to be sure that the model did not have overlapping factors.

The model in the current paper presented good adjustment indices in all requisites, as well as good convergent and divergent validity scores and construct reliability. Thus, after analysing the general model, the brands were ranked in terms of general average and average by construct as shown in Table 5 .

Table 5 - Brand averages concerning brand experience and dimension

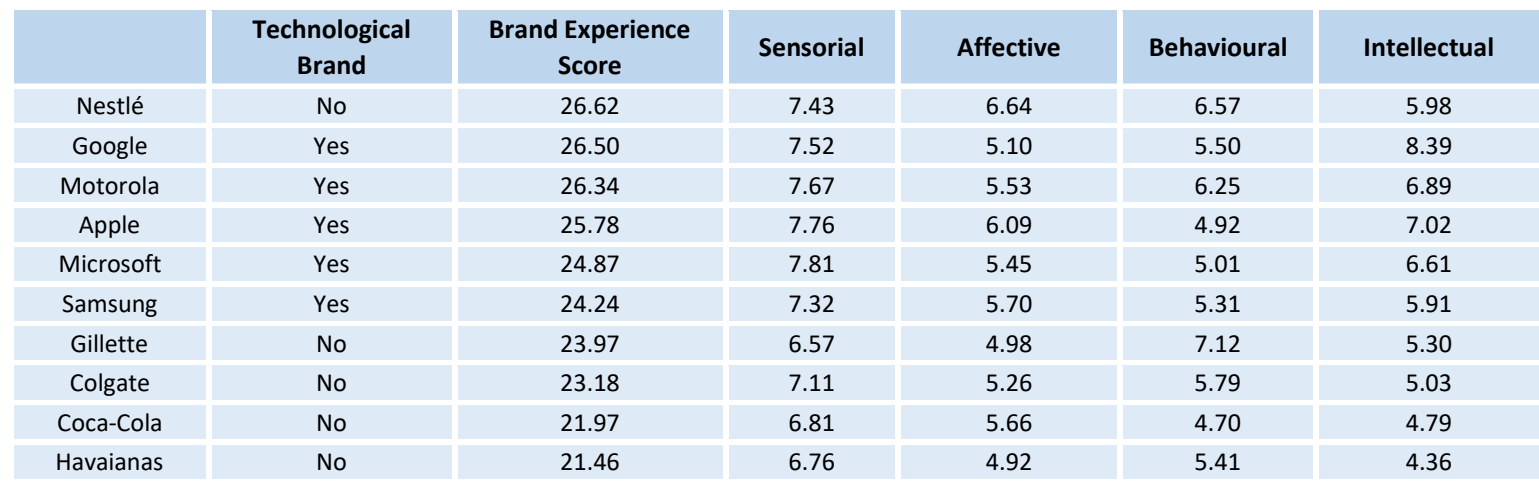

Nestlé presented the highest score for brand experience, whereas the Havaianas brand presented the lowest brand experience score among the tested brands. Nestlés good performance is justified by its high averages in all of the model's constructs, except for the intellectual dimension. The brands following Nestle with the next highest scores are all technological brands, with Google leading the pack and reaching the highest average among all brands for the intellectual dimension (8.39). The low averages for the affective dimension go against most studies done on brand experience: Fournier (2009), in her research, framed the Apple and CocaCola brands in the same quadrant: strong and intense experience, with a high degree of perceived social and emotional rewards. Apple obtained the second greatest average for the affective dimension, lagging behind only the Nestlé brand. However, these averages were indeed lower than those for other dimensions in this research. In the current study, these same brands did not present the same performance-with regard to neither the high degree of brand experience nor the affective dimension. Considering a group categorisation between technological and non-technological brands, ANOVA was estimated to test for any significant statistical differences among brand experience and its group dimension: technological and non-technological brands. Findings of these estimates are detailed in Table 6.

Table 6 - ANOVA test: Technological brands $\mathrm{x}$ non-technological brands

\begin{tabular}{|l|c|c|c|c|}
\hline \multicolumn{1}{|c|}{ Construct } & Brand Group & Average & Test F & Value for P \\
\hline \multirow{2}{*}{ Brand Experience } & Technological & 25.52 & 10.234 & 0.001 \\
\hline \multirow{2}{*}{ Sensorial } & Non-Technological & 23.37 & & 0.000 \\
\hline & Technological & 7.64 & 15.682 & 0.768 \\
\hline Affective & Non-Technological & 6.91 & & 0.051 \\
\hline \multirow{2}{*}{ Behavioural } & Technological & 5.57 & 0.087 & \\
\hline & Non-Technological & 5.51 & & 0.000 \\
\hline
\end{tabular}


According to the data in Table 6, consumers have a more relevant brand experience with technological brands than that with non-technological brands. One can also perceive that there is a statistically significant difference among groups when it comes to the sensorial dimension, which is linked to the individual's sensations regarding the tested brands, and the intellectual dimension, which is linked to the brand's capacity to challenge the consumer to search for solutions to his problems. In both dimensions, averages for technological brands were greater than averages for non-technological brands. Results suggest that brand experience for technology brands settles mainly on sensorial and intellectual dimensions. Therefore, efforts on multimedia will improve this experience as they enact how the brand interacts with each consumer Those results seem to answer an insight proposed by Brakus, Schmitt and Zarantonello (2014) that digital media, which are highly associated with technology brands, evoke more rational and intellectual appeal.

The behavioural dimension, which is linked to lifestyle, presented a higher average for technological brands; this difference was statistically significant with a $10 \%$ significance level. Thus, one cannot state that this dimension is useful for differentiating brand experience among groups in the same way as previous dimensions. Finally, the affective dimension, which is linked to emotions concerning the consumption situation, was the only dimension to present a superior average in the non-technological brands' group. The averages among groups came very close, which shows that this dimension is not useful for differentiating groups when it comes to brand experience.

Comparing the findings from this study with those of MorganThomas and Veloutsu (2013), which used a specific scale to measure technological brand experience, one notes the discrepancy when it comes to the importance of the emotional dimension: they highlight the growth of importance of the affective/emotional dimensions in the relationship with technological brands. In the model by Morgan-Thomas and Veloutsu, however, one notes that they obtained a high coefficient for perceived usability, a characteristic that is linked to the cognitive dimension and that presented the second greatest average in the current study. The findings of the current research also corroborates with Rose, Hair and Clark (2011) and Schmitt, Brakus and Zarantanello (2015), concerning to that consumers purchase (technological) brands for the experience, as it involves both rational and goal-orientated responses to the brand, and emotional processing of the total brand experience.

\section{Conclusion}

The goal of the current article was to identify any differences in brand experience between consuming technological and nontechnological brands, beginning with a scale developed by Brakus et al. (2009). The tested model was validated and the differences between groups were analyzed.

Results from the research show that consumers have a greater brand experience with the tested technological brands than that with the non-technological brands. This relationship with brands is established on the basis of two of the four factors that form the brand experience construct: the sensorial dimension that involves the senses and accurately reflects the consumer experience with the product or service and the intellectual dimension that links the technological brand user's cognitive capacity with his creative capacity and problem-solving skills. In both dimensions, technological brands obtained greater averages than the non-technological brands, demonstrating the importance of these dimensions when it comes to the technological brand experience.

The behavioural dimension, which involves the change in behaviour provided by brand experiences, presented low discriminant power among groups due to its low averages regarding previous dimensions, as well as due to the significance level (10\%) given by ANOVA. The affective dimension, which is linked to emotions in consumption situations of products or services, was the only dimension without group discriminant ability.

About empirical implications, the study presents some light on policies for advertising and developing a relationship with consumers, based on the nature of the brands. Considering that consumers incorporate the brand into their self-concepts (van der Westhuizen, 2018), and that technological sophistication is an important value-adding aspect for companies; CEOs of such companies should focus more on anchoring a relationship on sensorial and intellectual aspects of technological products in order to achieve enhanced financial performance.

The present study has limitations specifically regarding the student sample, which is the characteristic of methodology that may have impacted the interpretation of the findings. Authors have reported young consumers' need for connectedness (Behairy, Mukherjee, \& Venkatesh, 2006) and technological products are being evaluated by their "coolness", which includes characteristics such as trendiness, uniqueness, rebelliousness, genuineness and utility (Sundar, Tamul, \& Wu, 2014). Those findings related to youth might have an impact on the results achieved by the current research, once that it refers to a sample of higher education students. Further research is needed to test the current hypotheses considering a broader sample, considering a variety of generations. Besides, while analysis of data from members of one institution reduces generalizability, it increases correspondence to reality. Therefore, other contributions could also test how those dimensions are related in different contexts.

Finally, the results of this paper widen the field of research in brand management, thus offering a new approach in the context of technological brands. Thus, it helps in understanding the determinants that favour positive experiences it helps in understanding the determinants that favour positive experiences, reinforcing that the basis for a long-lasting brand relationship lies on its intensiveness, on its intellectual and sensorial challenging. 


\section{References}

Aaker, J.L. (1997). Dimensions of brand personality. Journal of Marketing Research, 34(3), 347-356.

Aaker, J.L., Benet-Martínez, V., \& Garolera, J. (2001). Consumption symbols as carriers of culture: A study of Japanese and Spanish brand personality constructs. Journal of Personality \& Social Psychology, 81(3), 492-508.

Aaker, J.L., Fournier, S., \& Brasel, A.D. (2008). When good brands do bad. Journal of Consumer Research, 31, 1-17.

Behairy, N., Mukherjee, S., \& Venkatesh, B. E. (2006). Technology-based communication patterns of youth. ACR North American Advances, 33, 304-305.

Brakus, J. J., Schmitt, B.H., \& Zarantonello, L. (2009). Brand Experience: What Is It? How Is It Measured? Does It Affect Loyalty? Journal of Marketing, 73(3), 52-68.

Breivik, E., \& Thorbjørnsen, H. (2008). Consumer brand relationships: an investigation of two alternative models. Journal of the Academy of Marketing Science, 36(4), 443-472.

Buchanan-Oliver, M., Cruz, A., \& Schroeder, J.E. (2010). Shaping the body and technology: discursive implications for the strategic communication of technological brands. European Journal of Marketing, 44(5), 635-652.

Escalas, J.E., \& Bettman, J.R. (2005). Self-Construal, Reference Groups, and Brand Meaning. Journal of Consumer Research, 32, 378-389.

Fournier, S. (2009). Lessons learned about consumers' relationships with their brands. In D. J. MacInnis, C. W. Park, \& J. R. Priester (Eds.), Handbook of brand relationships (pp. 5-23). Armonk, NY, US: M E Sharpe.

Fournier, S. (1998). Consumers and their brands: developing relationship theory in consumer research. Journal of Consumer Research, 24(4), 343-373.

Gentile, C., Spiller, N., \& Noci, G. (2007). How to Sustain the Customer Experience: European Management Journal, 25(5), 395-410.

Gil, A.C. (2002). Como escrever projetos de pesquisa. São Paulo: Atlas.

Gorbaniuk, O., Razmus, W., Firlej, K. Lebiedowicz, A., \& Leszczyńskig, M. (2017). Measuring corporate personality: A critical review and new insights. Journal of Brand Management, 24 (5), 423-438.

Hair Jr., J.F., Black, W.C., Babin, B.J., Anderson, R.E., \& Tatham, R.L. (2005). Multivariate Data Analysis. Porto Alegre: Bookman.

Heding, T., Knudtzen, C., \& Bjerre, M. (2009). Brand Management. Routledge.

Holbrook, M.B., \& Hirschman, E.C. (1982). The experiential aspects of consumption: consumer fantasies, feelings, and fun. Journal of Consumer Research, 9(2), 132-140.

Khan, I., \& Rahman, Z. (2015). A review and future directions of brand experience research. International Strategic Management Review, 3(12), 1-14.

Khan, I., \& Rahman, Z. (2016). Retail brand experience: scale development and validation. Journal of Product \& Brand Management, 25(5), 435-451.

Kinard, B.R., \& Capella, M.L. (2006). Relationship marketing: the influence of consumer involvement on perceived service benefits. Journal of Services Marketing, 20(6), 359-368.

Lee, H.J., \& Kang, M.S. (2012). The effect of brand experience on brand relationship quality. Academy of Marketing Studies Journal, 16(1): 87-98.

Malhotra, N.K. (2001). Pesquisa de Marketing. Porto Alegre: Bookman.

Marôco, J. (2010). Análise De Equações Estruturais - Fundamentos Teóricos, Software \& Aplicações. Pêro Pinheiro: Report Number, Lda.

Morgan-Thomas, A., \& Veloutsou, C. (2013). Beyond technology acceptance: Brand relationships and online brand experience. Journal of Business Research, 66(1), 21-27.

Mick, D.G., \& Fournier, S. (1998). Paradoxes of technology: consumer cognizance, emotions, and coping strategies. Journal of Consumer Research, 25(2), 123-143.
Pine, B. J., \& James H. G. (1998). Welcome to the experience economy. Harvard Business Review, 76, 97-105.

Pontes, M.C. (2012). Marketing experiencial ou o uso da experiência no marketing? Estudo de caso em hotéis 5 estrelas da cidade de São Paulo. (Unpublished doctoral dissertation), Universidade de São Paulo, São Paulo, Brasil.

Prado, P.H.M. (2004). A avaliação do relacionamento sob a ótica do cliente: um estudo em bancos do varejo. (Unpublished doctoral dissertation), Fundação Getúlio Vargas, São Paulo, Brasil.

Prahalad, C.K., \& Ramaswamy, V. (2004). Co-creation experiences: The next practice in value creation. Journal of Interactive Marketing, 18(3), 5-14.

Rose, S., Hair, N., \& Clark, M. (2011). Online customer experience: A review of the business-to-consumer online purchase context. International Journal of Management Reviews, 13(1), 24-39.

Rusbult, C.E. (1980). Commitment and satisfaction in romantic associations: A test of the investment model. Journal of Experimental Social Psychology, 16(2), 172-186.

Sabiote, E.F., \& Ballester, M.E.D. (2011). Marcas de experiencia: marcando la diferencia. Estudios Gerenciales, 27 (121), 59-77.

Schmitt, B. (2009). The concept of brand experience. Journal of Brand Management, 16, 417-419.

Schmitt, B.H., Brakus, J.J., \& Zarantonello, L. (2014). The current state and future of brand experience. Journal of Brand Management, 21(9), 727-733.

Schmitt, B. H., Brakus, J. J., \& Zarantonello, L. (2015). From experiential psychology to consumer experience. Journal of Consumer Psychology, 25(1), 166-171.

Seetharaman, P.B., Chib, S., Ainslie, A., Boatwright, P., Chan, T., Gupta, S., Mehta, N., Rao, V., \& Strijnev, A. (2005). Models of Multi-Category Choice Behavior. Marketing Letters, 16(3-4), 239-254.

Semprebom, E. (2010). A influência da experiência de consumo na qualidade de relacionamento dos universitários com suas marcas. (Unpublished master's thesis). Universidade Federal do Paraná, Curitiba, Brasil.

Semprebom, E. (2011, September). Experiência com Marca: validação da escala no contexto universitário. Proceedings of XXXV Encontro Anual da Associação Nacional de Pesquisa e Pós-Graduação em Administração, Rio de Janeiro, RJ, Brasil.

Shamim, A., \& Butt, M.M. (2013). A critical model of brand experience consequences. Asia Pacific Journal of Marketing and Logistics, 25(1), 102-117. Sherry Jr., J.F. (2006). Significado da Marca. In A.M. Tybout \& T. Calkins (Eds.) Branding: fundamentos, estratégias e alavancagem de marcas; implementação, modelagem e checklists; experiências de líderes de mercado (pp. 40-69). São Paulo: Atlas.

Sriram, S., Chintagunta, P.K., \& Agarwal, M.K. (2010). Investigating Consumer Purchase Behavior in Related Technology Product Categories. Marketing Science, 29(2), 291-314.

Stone, M., \& Woodcock, N. (1998). Marketing de Relacionamento. São Paulo: Littera Mundi.

Sundar, S. S., Tamul, D. J., \& Wu, M. (2014). Capturing "cool": Measures for assessing coolness of technological products. International Journal of Human-Computer Studies, 72(2), 169-180.

van der Westhuizen, L. M. (2018). Brand loyalty: exploring self-brand connection and brand experience. Journal of Product \& Brand Management, 27(2), 172-184.

Zaichkowsky, J.L. (1994). The personal involvement inventory: reduction, revision and application to advertising. Journal of Advertising, 23, 59-70.

\section{Received: 25.05 .2018}

Revisions required: 28.07 .2018

Accepted: 12.08 .2018 